\title{
Galectin-9 suppresses the growth of hepatocellular carcinoma via apoptosis in vitro and in vivo
}

\author{
KOJI FUJTAA $^{1}$, HISAKAZU IWAMA ${ }^{2}$, TEPPEI SAKAMOTO ${ }^{1}$, RYOICHI OKURA ${ }^{1}$, KIYOYUKI KOBAYASHI ${ }^{1}$, \\ JITSUKO TAKANO $^{1}$, AKIKO KATSURA ${ }^{1}$, MIWA TATSUTA ${ }^{1}$, EMIKO MAEDA ${ }^{1}$, SHIMA MIMURA ${ }^{1}$, \\ TAKAKO NOMURA $^{1}$, JOJI TANI ${ }^{1}$, HISAAKI MIYOSHI ${ }^{1}$, ASAHIRO MORISHITA ${ }^{1}$, HIROHITO YONEYAMA ${ }^{1}$, \\ YUKA YAMANA $^{1}$, TAKASHI HIMOTO ${ }^{1}$, KEIICHI OKANO ${ }^{3}$, YASUYUKI SUZUKI ${ }^{3}$, \\ TOSHIRO NIKI ${ }^{4}$, MITSUOMI HIRASHIMA ${ }^{4}$ and TSUTOMU MASAKI ${ }^{1}$ \\ ${ }^{1}$ Department of Gastroenterology and Neurology, ${ }^{2}$ Life Science Research Center, \\ Departments of ${ }^{3}$ Gastroenterological Surgery and ${ }^{4}$ Immunology and \\ Immunopathology, Kagawa University, Kagawa 761-079, Japan
}

Received February 3, 2015; Accepted March 11, 2015

DOI: 10.3892/ijo.2015.2941

\begin{abstract}
Galectin-9, a soluble $\beta$-galactoside-binding animal lectin, evokes apoptosis in various human cancer cell lines. The galectin-9 antitumor effect against hepatocellular carcinoma (HCC) is, however, unknown. We investigated whether galectin-9 suppresses HCC growth in vitro and in vivo. We assessed the antitumor effect of galectin-9 on HCC cells by conducting WST-8 assay in vitro and xenograft model analysis in vivo. Galectin-9-induced apoptosis was evaluated by FACS and ELISA in vitro and by TUNEL stain in vivo. Cell cycle alteration was profiled by FACS. Caspases were profiled by colorimetry. MicroRNAs related to the galectin- 9 antitumor effects were determined using microarrays, and their antitumor effect was confirmed in a transfection study in vitro. The expression levels of the target proteins of the miRNAs extracted above were analyzed by western blot analysis. To summarize the results, galectin-9 inhibited the growth of the HCC cell lines HLE and Li-7 in vitro and Li-7 in vivo inducing apoptosis. Cell cycle turnover was not arrested in HLE and Li-7 cells in vitro. miR-1246 was simi-
\end{abstract}

Correspondence to: Dr Tsutomu Masaki, Department of Gastroenterology, Kagawa University School of Medicine, Ikenobe 1750-1, Miki, Kagawa 761-079, Japan

E-mail: tmasaki@med.kagawa-u.ac.jp

Abbreviations: DMEM, Dulbecco's modified Eagle's medium; DYRK1A, dual specificity tyrosine (Y) phosphorylation-regulated kinase 1A; ELISA, enzyme linked immunosorbent assay; ER stress, endoplasmic reticulum stress; FACS, flow cytometric analysis; FBS, fetal bovine serum; HCC, hepatocellular carcinoma; PCR, polymerase chain reaction; PI, propidium iodide; SDS-PAGE, sodium dodecyl sulfate-polyacrylamide gel electrophoresis

Key words: hepatocellular carcinoma, galectin-9, apoptosis, miR-1246, DYRK1A larly extracted both in vitro and in vivo, which sensitized Li-7 cells to apoptosis when transfected into the cells. DYRK1A, a target protein of miR-1246 was downregulated in Li-7 cells. Caspase-9 was upregulated in Li-7 cells in vitro and in vivo. In conclusion, galectin-9 inhibited the growth of HCC cells by apoptosis, but not cell cycle arrest, in vitro and in vivo. miR-1246 mediated signals of galectin-9, possibly through miR-1246-DYRK1A-caspase-9 axis. Galectin-9 might be a candidate agent for HCC chemotherapy.

\section{Introduction}

Hepatocellular carcinoma (HCC) is the sixth most common cancer worldwide and the second leading cause of cancerrelated deaths (1). The application of potentially curative interventions such as liver transplantation, resection, and thermal ablation is limited to $\sim 30 \%$ of patients with tumors or liver function that meets defined criteria $(1,2)$. HCCs resist conventional systemic therapies. Although the standard systemic chemotherapy for patients with advanced HCC depends on the kinase inhibitor sorafenib, therapy with sorafenib resulted in a mean survival benefit of only 3 months $(3,4)$. Alternative agents for systemic therapy are urgently needed.

Galectin-9 is one of the soluble $\beta$-galactoside-binding animal lectins. It has been reported to trigger the death of $\mathrm{T}$-cell lines and various $\mathrm{T}$-cell subsets, resulting in immunomodulation with negative selection during T-cell development, in studies by us and others (5-9). Recent reports revealed the possibility that galectin- 9 can be applied to cancer therapy $(10,11)$. Galectin-9 induces apoptosis of chronic myelogenous leukemia cells and myeloma cells $(12,13)$. In addition to its induction of apoptosis in malignant melanoma cells, galectin-9 also arrested the cell cycle (14). Regarding the effects of galectin-9 on HCC, the cell surface expression of galectin-9 in HCC is considered to suppress metastasis and to improve the prognosis of cancer-bearing patients (15). 
The interaction of galectin- 9 and Tim-3, a specific ligand of galectin-9, was shown to mediate T-cell senescence in hepatitis B virus (HBV)-associated HCC (16), but the antitumor effect of galectin-9 on HCC was not determined. The purpose of the present study was to determine whether galectin- 9 can suppress the growth of HCC by inducing apoptosis and cell cycle arrest in vitro and in vivo. Another goal of the present study was to identify any microRNAs (miRNAs) associated with the antitumor effect of galectin-9.

\section{Materials and methods}

Antibodies and reagents. Recombinant mutant forms of human galectin-9 that lack the linker peptides were expressed and purified as described (17). Alexa Fluor ${ }^{\circledR} 647$ Annexin V, propidium iodide (PI), PE anti-human Tim-3 conjugated antibody (clone: F38-2E2) and its isotype, Human TruStain FcX IgG and Annexin V binding buffer were obtained from Biolegend (San Diego, CA, USA). Anti-DYRK1A antibody (ab65220) was provided by Abcam (Cambridge, UK). Anti$\beta$-actin monoclonal antibody (clone: AC-15) was supplied from Sigma-Aldrich (St. Louis, MO, USA).

Cell lines and culture. The HCC cell line HLE was obtained from the Japanese Cancer Research Resources Bank (Osaka, Japan). Li-7 and Huh7 were supplied by Riken Cell Bank (Tsukuba, Japan). The two Chinese hamster ovary (CHO) cell lines, CHO-K1 (Tim-3 knocked out cells) and CHO-Tim-3 (Tim-3 overexpressed cells), were gifts from Dr Vijay Kuchroo (Harvard Medical School). HLE, CHO-K1 and CHO-Tim-3 cells were grown in DMEM, Li-7 in RPMI-1640, and Huh7 in MEM, supplemented with $10 \%$ fetal bovine serum (FBS) and $100 \mathrm{mg} / \mathrm{l}$ of penicillin-streptomycin in a humidified atmosphere with $5 \%$ of $\mathrm{CO}_{2}$ at $37^{\circ} \mathrm{C}$.

Cell proliferation assay. Cell proliferation assays were conducted in HLE, Li-7 and Huh7 cells with WST-8 (18). Each cell type $\left(5 \times 10^{3}\right)$ was seeded into 96 -well plates and cultured in $100 \mu \mathrm{l}$ of culture medium for $24 \mathrm{~h}$. Cells were treated with $0.01,0.03,0.1,0.3$ or $1 \mu \mathrm{M}$ galectin-9. In addition, $30 \mathrm{mM}$ of lactose was added to inhibit the binding of galectin-9, and sucrose was used as a control (19).

FACS analysis. We conducted a flow cytometric analysis with Annexin V and PI to clarify whether galectin-9 has apoptotic and necrotic effects on $\operatorname{HCC}(18,20)$. Briefly, we treated HLE,

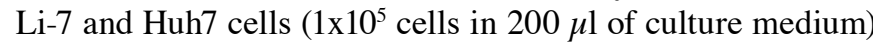
with $0.3 \mu \mathrm{M}$ galectin-9 for $12 \mathrm{~h}$ at $37^{\circ} \mathrm{C}$. The cells were analyzed with the Mofro Astrios flow cytometer (Beckman Coulter, Indianapolis, IN, USA). The results were analyzed by Kaluza software (Beckman Coulter).

The expression of Tim-3 on the cell surface was characterized by a single-color flow cytometric analysis (7). The $\mathrm{CHO}-\mathrm{K} 1$ cell line was used as the negative control and the CHO-Tim-3 cells were used as the positive control. HLE, CHO-K1 and CHO-Tim-3 cells were dissociated from a monolayer culture with enzyme-free cell dissociation buffer. Li-7 and Huh7 cells were dissociated with $0.05 \%$ of trypsin and incubated for $12 \mathrm{~h}$ in a non-adhesive 96-well microplate. The flow cytometric analysis was conducted using the
Cytomics FC 500 flow cytometer (Beckman Coulter), and the results were analyzed by Kaluza software.

We analyzed the effects of galectin-9 on the cell-cycle profile of HCC cells by using the Cell Cycle Phase Determination Kit (Cayman Chemical, Ann Arbor, MI, USA). The assays were conducted as described $(21,22)$. The flow cytometric analysis was conducted using the Cytomics FC 500 flow cytometer, and the percentage of cells in different phases of the cell cycle was analyzed using the Kaluza software.

ELISA assay for apoptosis. We evaluated the amounts of caspase-cleaved keratin18 (CCK18) by using the M30 Apoptosense ELISA kit (Peviva, Bromma, Sweden) (23). Each cell line $\left(5 \times 10^{3}\right)$ was seeded into 96 -well plates and cultured in $100 \mu \mathrm{l}$ of culture medium for $24 \mathrm{~h}$. The cells were then treated with $0.3 \mu \mathrm{M}$ galectin-9. The rest of the assay procedures were performed according to the manufacturer's instructions. The amounts of antigen in the controls and samples were calculated by interpolation into a standard curve.

Xenograft model analysis. Animal experiments were performed according to the guidelines of the Kagawa University Committee on Experimental Animals and the guidelines regarding the use of animals tissued by the UK National Cancer Research Institute (24).

We purchased female athymic mice (BALB/c-nu/nu; 8-week-old; 20-25 g) from Japan SLC (Shizuoka, Japan). The animals were maintained under specific pathogen-free conditions using a laminar air flow rack and had continuous free access to food sterilized by irradiation with $\gamma$-rays, which was purchased from CLEA Japan (Tokyo, Japan) and autoclaved water.

We used tissues instead of cell suspensions for the xenograft model of Li-7 cells because a 90-day period would be necessary for the tumors to grow to palpable size in mice injected with a cell suspension of Li-7 cells. Li-7 tissues were transplanted subcutaneously (s.c.) in the flank of nude mice for initial passage. The tumor tissues were harvested when the tumors grew to $15 \mathrm{~mm}$ in diameter, and the tumor tissue was cut into pieces $3 \mathrm{~mm}$ in diameter.

Mice were inoculated with a tumor fragment of Li-7 (25). Huh7 cells $\left(2 \times 10^{6}\right.$ cells per animal) were also injected s.c. in nude mice. When the xenografts were palpable as a mass of $>6 \mathrm{~mm}$ in diameter in all recipients, the mice were randomly assigned to the control group or a treated group. Treated mice $(n=6)$ were injected s.c. with galectin-9 $(90 \mu \mathrm{g})$ three times a week. Only phosphate-buffered saline (PBS) was administered to the control group $(n=6)$. The tumor growth was monitored by the same investigators (K. Fujita and T. Masaki). The tumor volume was calculated as follows: tumor volume $\left(\mathrm{mm}^{3}\right)=$ tumor length $(\mathrm{mm}) \times$ tumor width $\left.\left(\mathrm{mm}^{2}\right)\right] / 2$. The animals bearing an excessive tumor volume $\left(>2,000 \mathrm{~mm}^{3}\right)$ were euthanized for ethical reasons (24).

TUNEL assay. The tumor tissues were fixed in $4 \%$ buffered paraformaldehyde. We performed a terminal deoxynucleotidyl transferase dUTP nick end labeling (TUNEL) assay to detect apoptotic cells using the TACS2 TdT-DAB In Situ Apoptosis Detection kit (Trevigen, Gaithersburg, MD, USA) according to the manufacturer's instructions (18). 

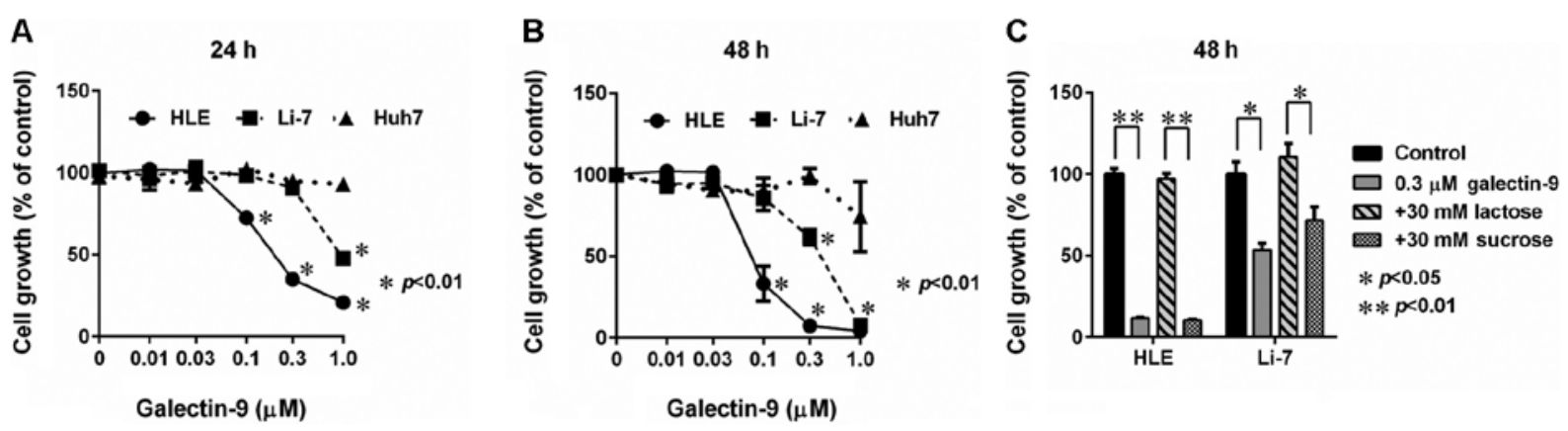

Figure 1. Galectin-9 suppresses cell proliferation of the human hepatocellular carcinoma cell lines HLE and Li-7. The inhibitory effect of galectin-9 on cell proliferation was assessed by WST- 8 assay after incubation with galectin-9 for $24 \mathrm{~h}$ (A) and 48 h (B). The growth of Huh7 cells was not suppressed by galectin-9. Data are the percent of control (mean $\pm \mathrm{SD}, \mathrm{n}=6$, and the ${ }^{*} \mathrm{p}$-values were calculated in comparison with the controls of the same cell line). (C) The antagonistic effect of lactose against galectin- 9 was assessed by WST- 8 assay. Cells were incubated with or without 30 mM lactose in addition to $0.3 \mu \mathrm{M}$ galectin- 9 for $48 \mathrm{~h}$. The effect of galectin- 9 was antagonized by lactose, suggesting that the $\beta$-galactoside binding nature of galectin- 9 is essential for the activity. Data are the percent of the control (mean $\pm \mathrm{SD}, \mathrm{n}=6$ ). The p-values were calculated in comparison with the control; ${ }^{*} \mathrm{p}<0.05{ }^{* *} \mathrm{p}<0.01$.

Colorimetric assay for caspase-4, -8 and -9 . We determined the amount of caspase- $4,-8$ and -9 by using the caspase- 4 , FLICE/caspase- 8 and caspase- 9 colorimetric assay kits (BioVision, Milpitas, CA, USA), respectively (18). HLE and Li-7 cells were cultured with or without $0.3 \mu \mathrm{M}$ galectin-9, and the subsequent procedures were performed according to the manufacturer's instructions.

Analysis of miRNA microarray. We extracted the total RNA of cultured cells or tumor tissues using the miRNeasy Mini kit (Qiagen, Venlo, The Netherlands) as described $(21,22,26)$. Cells were cultured with or without galectin- 9 for $24 \mathrm{~h}$ in pentaplicate. The samples were labeled using a miRCURY Hy3 Power Labeling kit (Exiqon, Vedbaek, Denmark) and hybridized on a human miRNA Oligo chip, version 14.0 (Toray, Tokyo, Japan). Scanning was conducted with the 3D-Gene Scanner 3000 (Toray). We used 3D-Gene extraction software (ver. 1.2, Toray) to read the raw intensity of the image. The raw data were analyzed with GeneSpringGX (ver. 10.0, Agilent Technologies, Santa Clara, CA, USA) and quantile normalized (27). We calculated the fold changes in miRNA expression level between the treated groups and control group. Hierarchical clustering was accomplished using the furthest neighbor method and Pearson's product-moment correlation coefficient as a metric.

Transfection of miRNA. Li-7 cells were transfected with miR-1246 mimic (mirVana miRNA mimic, Ambion, Carlsbad, CA, USA), miR-6131 mimic, and Lipofectamine 2000 according to the manufacturer's protocol. HCC cells were transfected with miR-1246 mimic, miR-6131 mimic, or negative control \#1 (Ambion) under galectin-9. The WST-8 assay and ELISA of CCK18 were conducted at the indicated time-points.

Western blot analysis. The cell lysate was processed according to the methods described in our previous reports $(21,22)$. All the steps were carried out at $4^{\circ} \mathrm{C}$. Protein concentrations were measured with a spectrophotometer NanoDrop 2000 (Thermo Fisher Scientific, Wilmington, DE, USA). Samples were electrophoresed through $10 \%$ SDS-PAGE, and the proteins were transferred to nitrocellulose membranes. The membranes were incubated with primary antibodies after blocking and then incubated with horseradish peroxidase (HRP)-conjugated secondary antibodies. Immunoreactive proteins were visualized with an enhanced chemiluminescence detection system (Perkin-Elmer, San Jose, CA, USA) on X-ray film.

Bioinformatics. Target sites for miR-1246 found in DYRK1A 3'UTR are aligned among 16 mammals by TargetScan.

Statistical analysis. Data were analyzed by paired t-test for tumor volumes in vivo, which were analyzed by two-way repeated-measures analysis of variance (ANOVA). P-values $<0.05$ were recognized as significant. All statistical analyses were performed with Prism 6 software (Graph Pad Software, La Jolla, CA, USA).

\section{Results}

Galectin-9 inhibits the cell proliferation of HLE and Li-7 cells in vitro by inducing apoptosis. We screened the inhibitory effect of galectin-9 on HCC by performing a WST-8 assay, and we found that galectin- 9 inhibited the cell proliferation of the HLE and Li-7 cell lines in a dose- and time-dependent manner. The inhibition of cell proliferation was more evident in the HLE cells than the Li-7 cells. However, no anti-proliferative effect of galectin-9 was detected in Huh7 cells (Fig. 1A and B). The effect of galectin- 9 was antagonized by $30 \mathrm{mM}$ lactose, suggesting that the $\beta$-galactoside binding nature of galectin- 9 is essential for the activity (Fig. 1C).

We then performed flow cytometric analysis to assess the contribution of apoptosis and necrosis to the suppression of tumor growth. As shown in Fig. 2A and B, the antiproliferative effects of galectin-9 on the HLE and Li-7 cells was not due to necrosis, but rather to the induction of an early apoptotic change that was Annexin V-positive and PI-negative $(18,20)$. The Huh7 cells did not exhibit early apoptotic or necrotic changes after treatment with galectin-9. These results resemble the data of WST-8 assay (Fig. 1A and B).

We determined the levels of CCK18 by ELISA to establish whether apoptosis is involved in galectin-9-induced cell death, and we found that galectin-9 increased the levels of CCK18 in HLE and Li-7 cells as illustrated in Fig. 2C, suggesting that the apoptotic process following phosphatidylserine expo- 
A
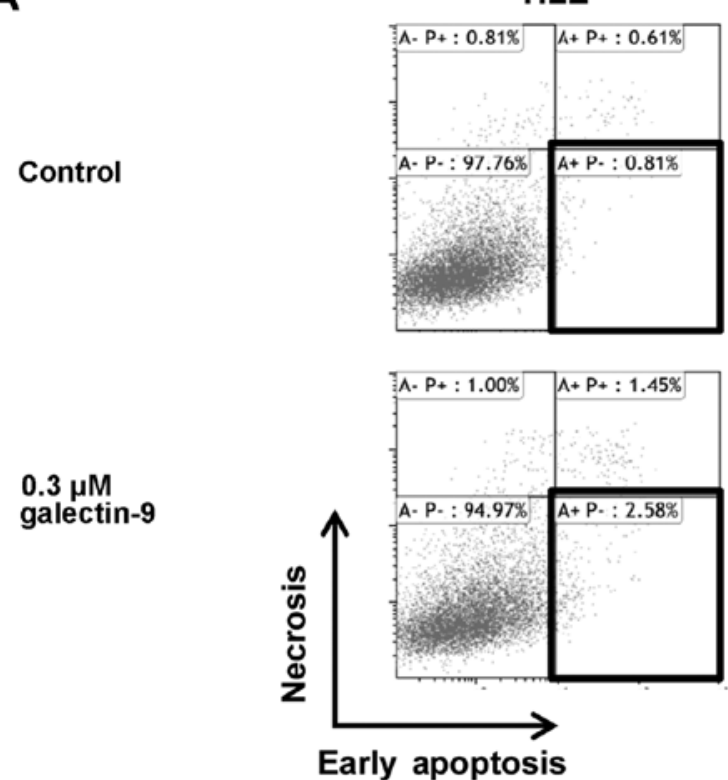

Early apoptosis
Li-7
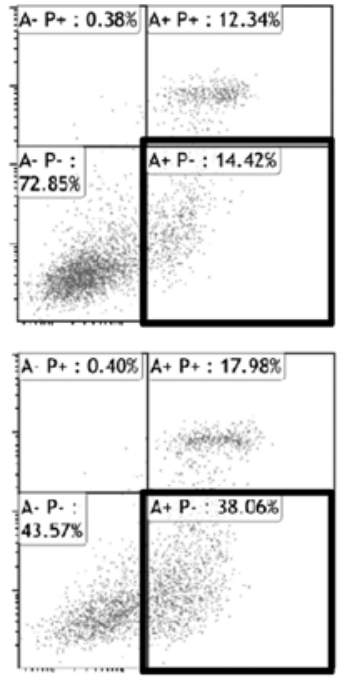

Huh7
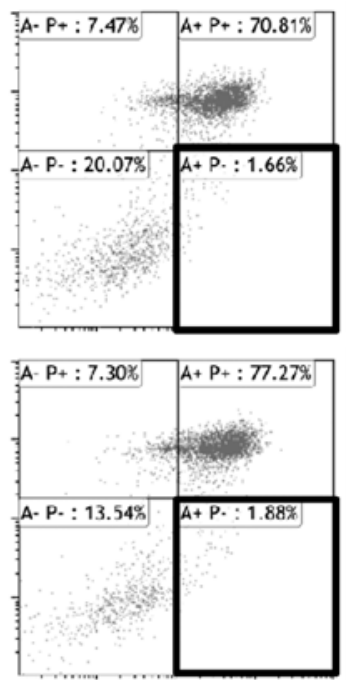

B

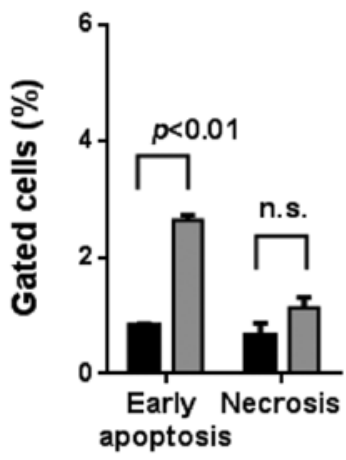

HLE

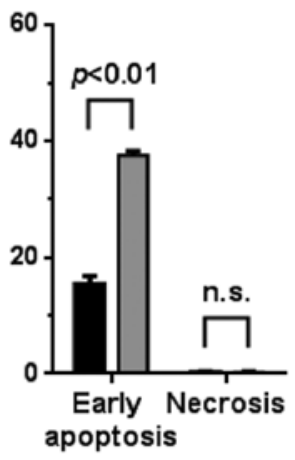

Li-7

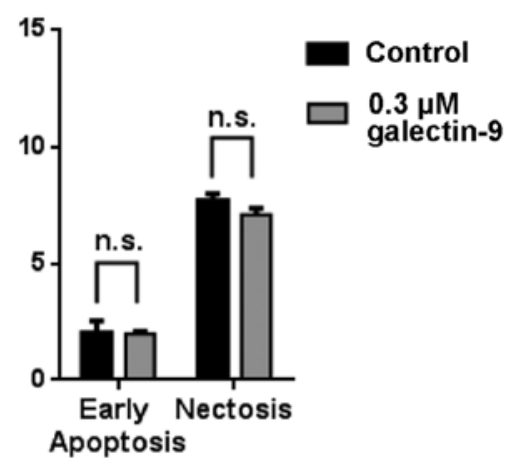

Huh7
C

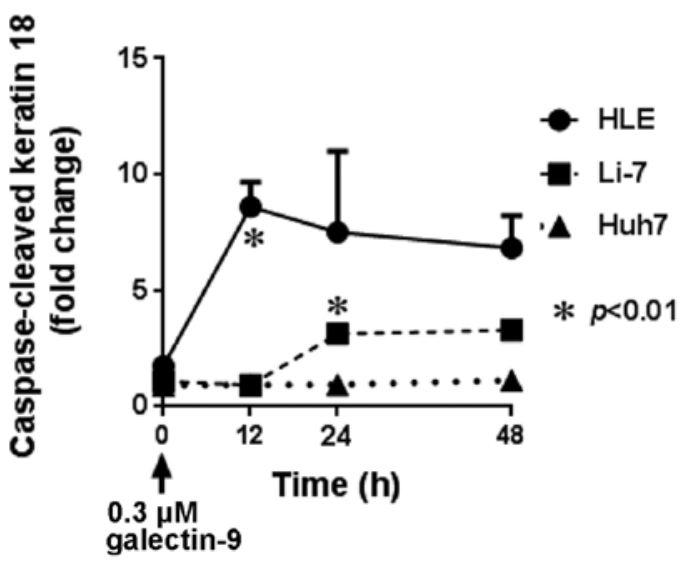

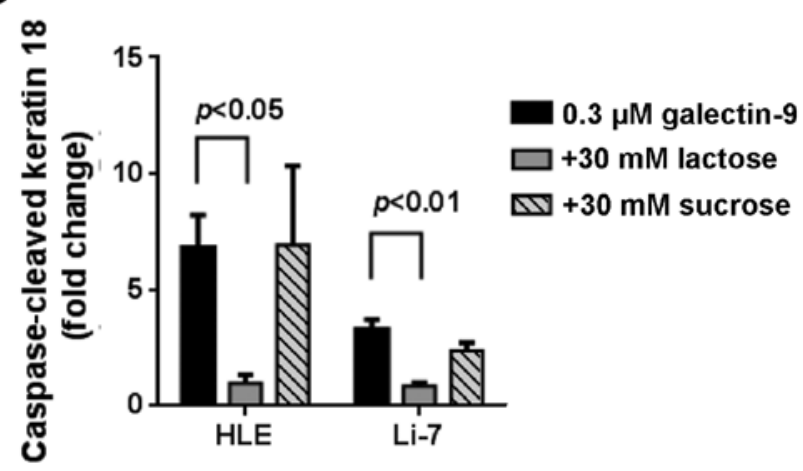

Figure 2. Galectin-9 induces apoptosis in HLE and Li-7 cells depending on the $\beta$-galactoside binding region. Both the early apoptotic changes and necrotic changes evoked by galectin- 9 were assessed by a flow cytometry analysis. The analysis was performed after incubation with $0.3 \mu \mathrm{M}$ galectin- 9 for $12 \mathrm{~h}$. Cells were stained with Annexin V and propidium iodide (PI). Annexin V-positive and PI-negative cells were regarded as early-apoptotic (enclosed areas in bold squares). Annexin V-negative and PI-positive cells were regarded as necrotic. (A) The representative data of each cell line. (B) Data are mean \pm SD with analysis by paired t-test $(n=6)$. These data revealed that galectin-9 significantly induced early apoptotic change (p<0.01) in HLE and Li-7 cells, and not in Huh7 cells. Galectin-9 did not induce necrotic changes in HLE, Li-7 or Huh7 cells. (C) CCK18 produced specifically in apoptosis was determined by an ELISA. Cells were incubated with or without $0.3 \mu \mathrm{M}$ galectin-9. Galectin-9 increased the levels of CCK18 in HLE and Li-7 cells, suggesting that the apoptotic process following phosphatidylserine exposure proceeds to cut intermediate filaments of cells. The fold change of CCK18 is shown as mean \pm SD with analysis by paired t-test $(n=6)$. (D) The antagonistic effect of lactose against galectin-9 was assessed by an ELISA of CCK18. Cells (HLE and Li-7 cells) were incubated with or without $30 \mathrm{mM}$ lactose in addition to $0.3 \mu \mathrm{M}$ galectin- 9 for $24 \mathrm{~h}$. Cleavage of keratin 18 was significantly inhibited (p<0.05) by lactose, an antagonist of galectin-9. The data suggest that the $\beta$-galactoside binding site of galectin-9 is necessary for apoptosis. The fold change of CCK18 is shown as mean \pm SD with analysis by paired t-test $(n=6)$. 
A
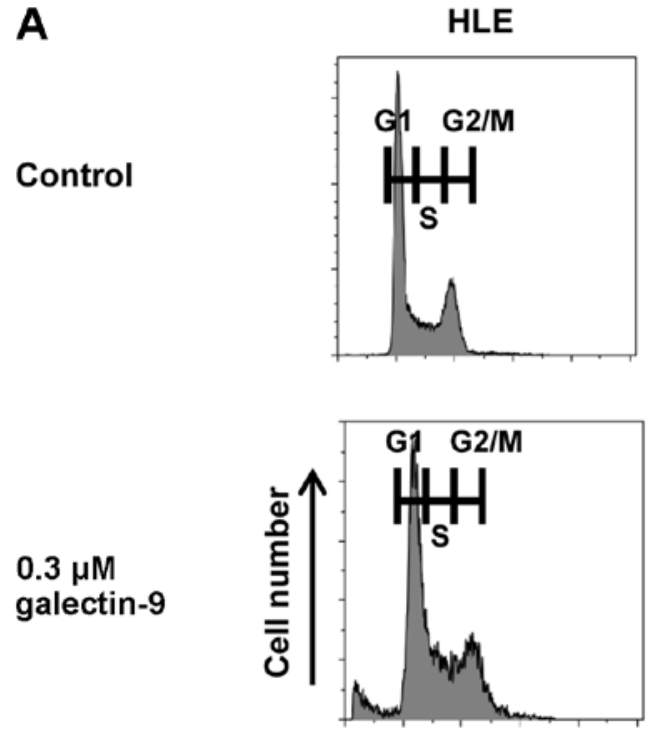

Li-7
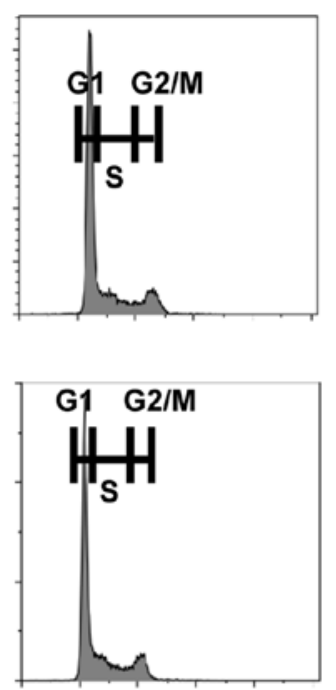

Huh7
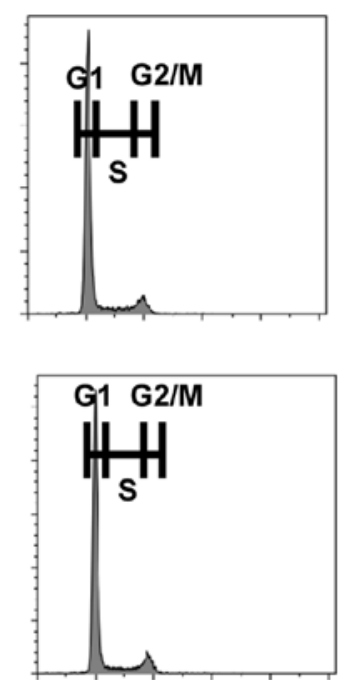

B

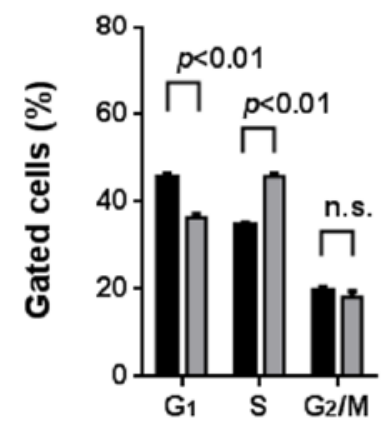

HLE

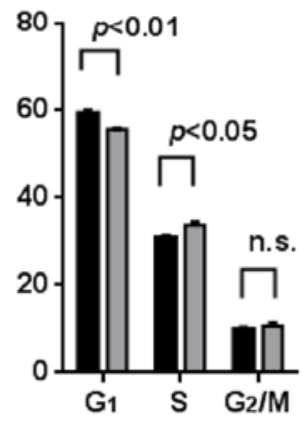

Lì-7

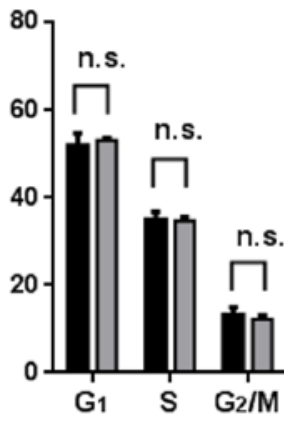

Huh7

C

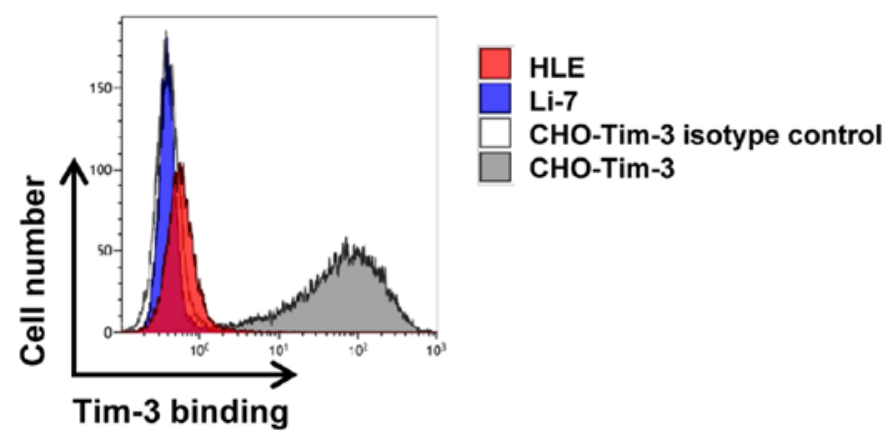

Figure 3. Flow cytometric analysis of galectin-9 on the cell cycle in HLE, Li-7 and Huh7 cells. We assessed the alteration of cell cycle profiling induced by galectin- 9 by a flow cytometry assay after the incubation of cells with $0.3 \mu \mathrm{M}$ galectin- 9 for $48 \mathrm{~h}$. Cells were harvested and stained with PI. (A) Representative data of each cell line. (B) Data are mean \pm SD with analysis by paired $t$-test $(n=3)$. The proportion of cells in S phase was significantly increased in the HLE $(\mathrm{p}<0.01)$ and Li-7 $(\mathrm{p}<0.05)$ cells. $(\mathrm{C})$ Expression of Tim-3 on the cell surface was assessed by flow cytometry. Cells were incubated for $12 \mathrm{~h}$ in non-adhesive wells after enzymatic dissociation with trypsin, and stained with anti-Tim-3-PE antibody. CHO-K1, negative control; CHO-Tim-3, positive control. Tim-3 was not detected on the cell surface of HLE or Li-7 cells, suggesting that galectin-9 induced apoptosis of HCCs independently of Tim-3.

sure proceeds to cut intermediate filaments of cells (23). A galectin-9-induced increase in CCK18 was also inhibited by one of the antagonists of galectin-9, $30 \mathrm{mM}$ lactose, compared to $30 \mathrm{mM}$ sucrose (Fig. 2D).

Effects of galectin-9 on the cell cycle in HLE, Li-7 and Huh7 cells. We further performed a flow cytometric analysis of the cell cycle to evaluate the contribution of cell cycle arrest to the suppression of HCC cell lines by galectin-9. HLE, Li7, and Huh7 cells were treated with $0.3 \mu \mathrm{M}$ galectin- 9 , and we observed that the proportion of cells in S phase was very slightly increased in the HLE and Li-7 cells with the treatment by galectin- 9 (Fig. 3A and B). These results suggested that galectin-9 inhibits tumor growth predominently through cancer cell apoptosis. 
A

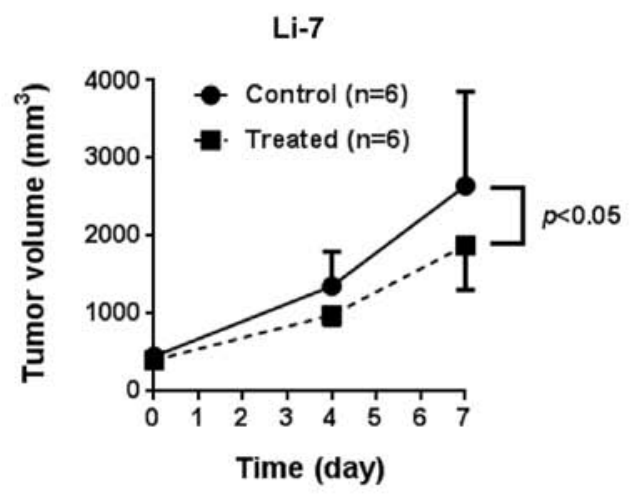

Huh7

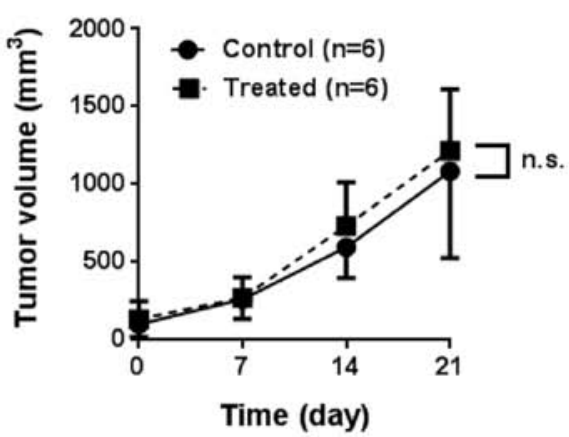

B

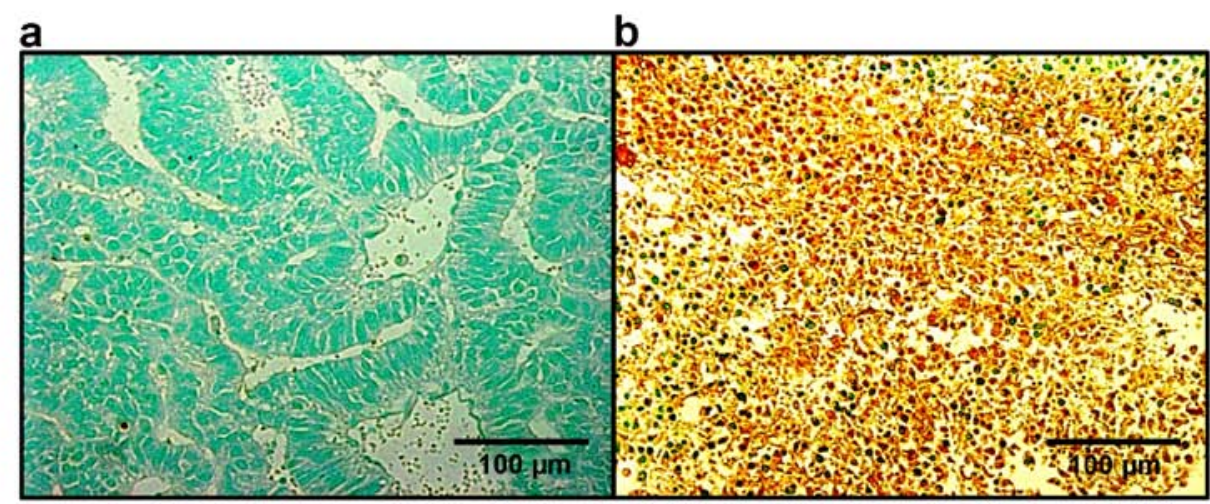

Control

Treated

C

Li-7 in vitro

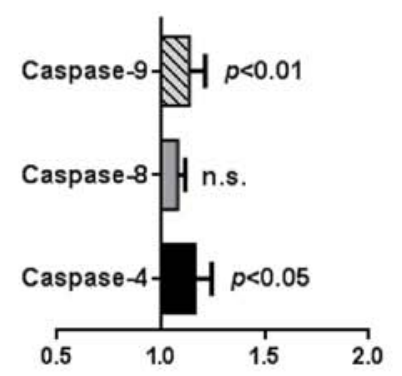

Fold change (Treated / Control)
Li-7 in vivo

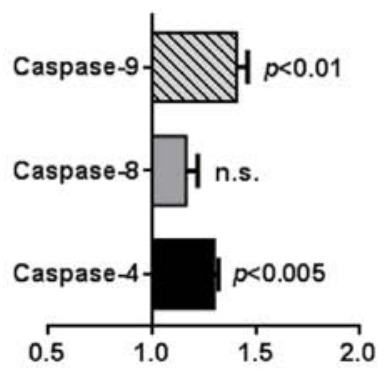

Fold change (Treated / Control)

Figure 4. In vivo antitumor effects of galectin-9 on established HCC (A and B) and caspase profiling in vitro and in vivo (C). (A) Xenograft model analysis using Li-7 and Huh7 cells. Tissue fragments of Li-7 or a cell suspension of Huh7 were transplanted subcutaneously (s.c.) in the left flank of 6-week-old female nude mice. The mice were assigned randomly to two groups when the average tumor volume reached $100 \mathrm{~mm}^{3}$. Galectin-9 $(90 \mu \mathrm{g})$ was injected s.c. every $2 \mathrm{nd}$ day into the right flank in the treated group, and PBS was injected in the control group. The tumor volume was calculated as (length)(width) $)^{2} / 2$. Data are mean $\pm \mathrm{SD}$ analyzed by two-way ANOVA $(\mathrm{n}=6)$. The Li-7 tumors in the treated mice were significantly smaller than those in the controls $(\mathrm{p}<0.05)$; the tumors of Huh7 were not suppressed. (B) Sections obtained from xenografts of Li-7 stained by the TUNEL method for apoptosis. (a) Section of the xenograft from the treated group. (b) Control group xenograft section. The induction of apoptosis was detected in the cancer tissue of galectin-9-treated mice. (C) Caspase- $4,-8$, and -9 were determined by colorimetry. The in vitro assay was performed after incubation with $0.3 \mu \mathrm{M}$ galectin- 9 for $24 \mathrm{~h}$. The in vivo assay was conducted using protein extracts from the xenografts. Caspase- 4 and -9 were upregulated with the galectin- 9 treatment. Caspase- 8 was not changed by galectin- 9 treatment, suggesting that caspase- 8 does not have a role in galectin-9-induced apoptosis. The fold change of each caspase is presented as the mean \pm SD, analyzed by paired $\mathrm{t}$-test $(\mathrm{n}=6)$.

Galectin-9 induces apoptosis in HCC cell lines independently of Tim-3. The cell surface expression of Tim-3, a specific ligand of galectin-9, was assessed by flow cytometric analysis because we speculated that a Tim-3/galectin-9 pathway is also involved in apoptosis of HCC cells, similarly to T lymphocytes (7). Intriguingly, we were not able to detect evident Tim-3 on HLE or Li-7 cells, suggesting that galectin-9 induces apoptosis of HCC cells through binding with an unknown ligand other than Tim-3 (Fig. 3C).

Galectin-9 inhibits the growth of Li-7 cells in vivo by inducing apoptosis. To determine whether galectin-9 affects tumor growth in vivo, we performed experiments with a xenograft animal model. As shown in Fig. 4A, galectin-9 significantly 
Table I. Statistical results and chromosomal locations of miRNAs in Li-7 cells treated with galectin-9, compared to control cells $(\mathrm{p}<0.05)$

\begin{tabular}{lccc}
\hline Name & $\begin{array}{c}\text { Fold } \\
\text { (treated/control) } \\
\text { mean } \pm \text { SD }\end{array}$ & p-value & $\begin{array}{c}\text { Chromosomal } \\
\text { localization }\end{array}$ \\
\hline Upregulated & & & \\
miR-4294 & $3.04 \pm 1.22$ & 0.023 & 10 \\
miR-1227-5p & $2.96 \pm 1.33$ & 0.008 & 19 \\
miR-642b-3p & $2.41 \pm 0.86$ & 0.020 & \\
miR-6131 & $2.22 \pm 0.66$ & 0.001 & 5 \\
miR-1246 & $1.83 \pm 0.46$ & 0.003 & $2 \mathrm{q} 31.1$ \\
miR-4289 & $1.82 \pm 0.58$ & 0.016 & 9 \\
miR-3621 & $1.78 \pm 0.45$ & 0.010 & 9 \\
miR-3960 & $1.69 \pm 0.38$ & 0.004 & 9 \\
miR-1237-5p & $1.64 \pm 0.33$ & 0.001 & 11 \\
miR-4257 & $1.62 \pm 0.40$ & 0.025 & 1 \\
miR-4485 & $1.61 \pm 0.40$ & 0.050 & 11 \\
miR-4463 & $1.50 \pm 0.31$ & 0.034 & 6 \\
Downregulated & & & 17 \\
miR-142-5p & $0.45 \pm 0.39$ & 0.040 & 7 \\
miR-489 & $0.42 \pm 0.43$ & 0.044 & \\
\hline & & & \\
\hline
\end{tabular}

amiRNAs that were matched to miRNAs extracted from cultured cells $(p<0.05)$ and tumor tissues of xenografts $(p<0.005)$.

inhibited the tumor growth of Li-7 cells on day 7. On the contrary, the tumor growth of Huh7 cells was not suppressed in vivo with the treatment of galectin-9 (Fig. 4A). The antitumor effect in vivo resembled that observed in our in vitro experiments. The groups of mice did not show any significant differences in body weight or water consumption.

Influence of apoptosis in xenografts treated with and without galectin-9. Apoptotic cells were detected by TUNEL assay in the tissues of Li-7 treated with galectin-9 as presented in Fig. 4B-b. However, apoptotic cells were not detected in control tissues (Fig. 4B-a). The results of the xenograft model analysis matched those observed in vitro.

Galectin-9 increases the levels of caspase-9 and -4. We assessed the levels of caspase-4, -8 and -9 to clarify whether endoplasmic reticulum stress (ER stress), death receptor or mitochondrial pathway contributes to apoptosis induced by galectin-9 (28). The results of our in vitro and in vivo experiments (Fig. 4C) showed that the levels of caspase-4 and -9 were upregulated with the galectin- 9 treatment, whereas caspase- 8 was not changed by the galectin- 9 treatment, suggesting that ER stress and mitochondrial pathway were involved in galectin-9-induced apoptosis.

miRNA profiling of Li-7 in vitro and in vivo. To investigate the intracellular pathway of apoptosis, we screened the expression levels of miRNAs in Li-7 cells and xenografts, and we
Table II. Statistical results and chromosomal locations of miRNAs in xenografts from the treated group, compared to those from the control group $(\mathrm{p}<0.005)$.

\begin{tabular}{|c|c|c|c|}
\hline Name & $\begin{array}{c}\text { Fold } \\
\text { (treated/control) } \\
\text { mean } \pm \mathrm{SD}\end{array}$ & p-value & $\begin{array}{c}\text { Chromosomal } \\
\text { localization }\end{array}$ \\
\hline \multicolumn{4}{|l|}{ Upregulated } \\
\hline $\operatorname{miR}-1246^{\mathrm{a}}$ & $2.76 \pm 0.75$ & 0.0027 & $2 q 31.1$ \\
\hline $\operatorname{miR}-6075$ & $2.39 \pm 0.59$ & 0.0040 & 5 \\
\hline $\operatorname{miR}-3180$ & $2.34 \pm 0.69$ & 0.0031 & \\
\hline miR-6076 & $2.23 \pm 0.40$ & 0.0024 & 14 \\
\hline $\operatorname{miR}-4459$ & $2.19 \pm 0.46$ & 0.0033 & 5 \\
\hline $\operatorname{miR}-6131^{\mathrm{a}}$ & $1.98 \pm 0.44$ & 0.0031 & 5 \\
\hline miR-1908 & $1.93 \pm 0.28$ & 0.0016 & 11 \\
\hline miR-4749-5p & $1.86 \pm 0.28$ & 0.0005 & 19 \\
\hline miR-1909-3p & $1.74 \pm 0.44$ & 0.0007 & $19 p 13.3$ \\
\hline miR-3940-5p & $1.71 \pm 0.21$ & 0.0033 & 19 \\
\hline miR-4763-3p & $1.68 \pm 0.32$ & 0.0021 & 22 \\
\hline $\operatorname{miR}-4530$ & $1.65 \pm 0.21$ & 0.0016 & 19 \\
\hline $\operatorname{miR}-3196$ & $1.60 \pm 0.21$ & 0.0012 & 20 \\
\hline $\operatorname{miR}-4730$ & $1.50 \pm 0.22$ & 0.0045 & 17 \\
\hline \multicolumn{4}{|l|}{ Downregulated } \\
\hline miR-140-5p & $0.67 \pm 0.14$ & 0.0015 & $16 q 22.1$ \\
\hline let $-7 g-5 p$ & $0.67 \pm 0.11$ & 0.0011 & $3 p 21.1$ \\
\hline miR-660-5p & $0.66 \pm 0.10$ & 0.0008 & $\mathrm{Xp} 11.23$ \\
\hline $\operatorname{miR}-23 a-3 p$ & $0.66 \pm 0.09$ & 0.0035 & $19 \mathrm{p} 13.13$ \\
\hline miR-708-5p & $0.65 \pm 0.14$ & 0.0019 & $11 \mathrm{q} 14.1$ \\
\hline miR-30e-5p & $0.65 \pm 0.16$ & 0.0024 & $1 \mathrm{p} 34.2$ \\
\hline miR-378g & $0.64 \pm 0.09$ & 0.0017 & \\
\hline $\operatorname{miR}-92 a-3 p$ & $0.64 \pm 0.11$ & 0.0021 & \\
\hline miR-17-3p & $0.62 \pm 0.21$ & 0.0021 & $13 \mathrm{q} 31.3$ \\
\hline miR-339-5p & $0.61 \pm 0.12$ & 0.0036 & $7 \mathrm{p} 22.3$ \\
\hline miR-4664-5p & $0.60 \pm 0.11$ & 0.0025 & 6 \\
\hline $\operatorname{miR}-532-5 p$ & $0.59 \pm 0.10$ & 0.0021 & $\mathrm{Xp} 11.23$ \\
\hline miR-4443 & $0.58 \pm 0.08$ & 0.0007 & 3 \\
\hline miR-30c-5p & $0.57 \pm 0.10$ & 0.0004 & \\
\hline miR-10a-5p & $0.53 \pm 0.09$ & 0.0026 & $17 q 21.32$ \\
\hline miR-152 & $0.53 \pm 0.17$ & 0.0020 & $17 q 21.32$ \\
\hline
\end{tabular}

${ }^{a}$ miRNAs that were matched to miRNAs extracted from cultured cells $(p<0.05)$ and tumor tissues of xenografts $(p<0.005)$.

compared the miRNA profiles obtained with or without galectin-9. We used cells treated with galectin-9 for $24 \mathrm{~h}$ as in vitro samples and xenografts as the in vivo samples. The unsupervised hierarchical clustering analysis showed that the treated group clustered together and separately from the controls both in vitro and in vivo (Fig. 5).

We identified 14 miRNAs that were differently expressed (12 upregulated and two downregulated miRNAs) in culture (Table I) and 30 miRNAs differently expressed (14 upregulated and 16 downregulated) in xenograft tumor tissues (Table II). 

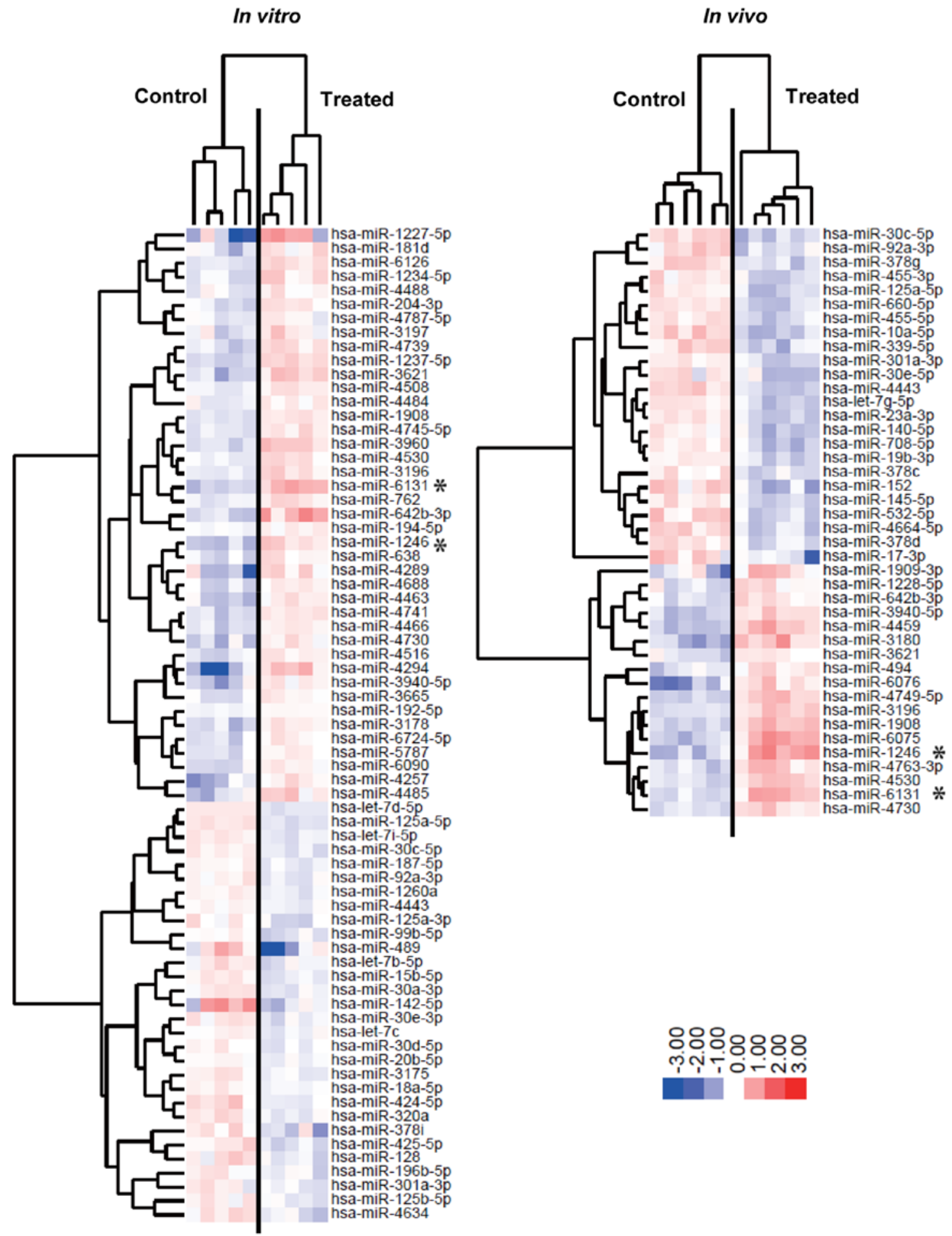

Figure 5. Hierarchical clustering of miRNAs from cultured cells and xenografts. Hierarchical clustering was performed for miRNA expression profiles of the controls and the galectin-9-treated samples from cultured cells (left-side panel) and tumor tissues (right-side). Samples are arranged in columns and miRNAs in rows. The miRNA clustering tree is shown on the left and the sample clustering tree is shown at the top of each heat map. Heat maps show the relative expression intensity for each miRNA in which the base-2 logarithm of the intensity is median-centered for each row. The color-coding is indicated as a horizontal bar. The two miRNAs with an asterisk are common between the in vitro $(\mathrm{p}<0.05)$ and in vivo $(\mathrm{p}<0.005)$ results regardless of fold change.

We found that two miRNAs, miR-1246 and miR-6131, were upregulated in both cultured cells and tumor tissues treated with galectin-9.

The microarray data obtained in this study are registered at the NCBI Gene expression Omnibus (GEO). The accession numbers are GSE55665 for the in vitro data and GSE55666 for the in vivo data.
miR-1246 enhances the apoptosis of Li-7 cells when galectin-9 is administered. We performed a WST-8 assay to determine whether the miR-1246 upregulated with galectin-9 treatment contributes to galectin-9-induced apoptosis. As shown in Fig. 6A, the tumor growth was inhibited in the transfection of miR-1246 in Li-7 cells under $0.1 \mu \mathrm{M}$ galectin- 9 treatment, but the suppression of tumor growth was not detected in the trans- 
A

$$
0.1 \mu \mathrm{M} \text { galectin-9 }
$$

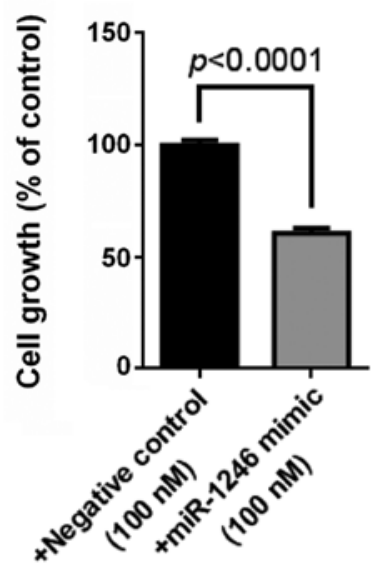

B $\quad 0.1 \mu \mathrm{M}$ galectin-9

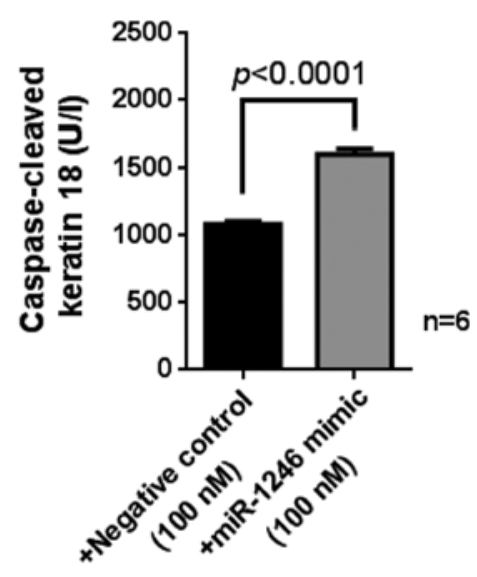

PBS

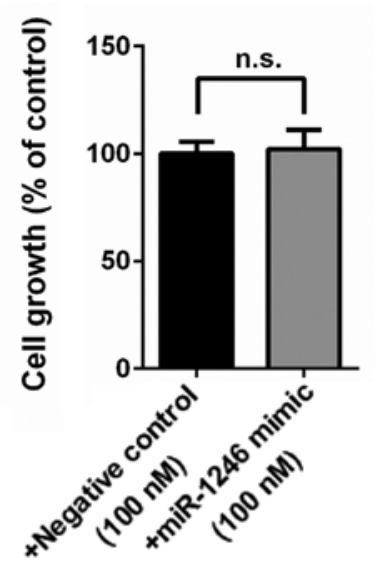

C $\quad 0.1 \mu \mathrm{M}$ galectin-9

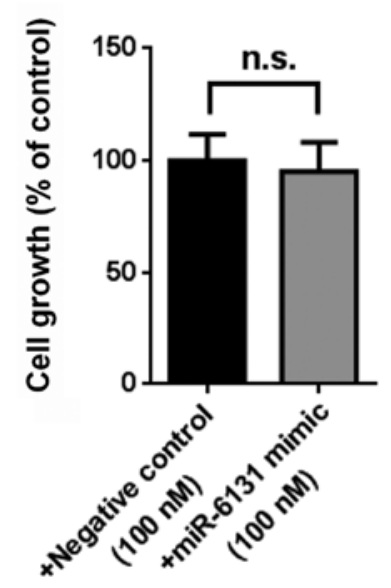

D

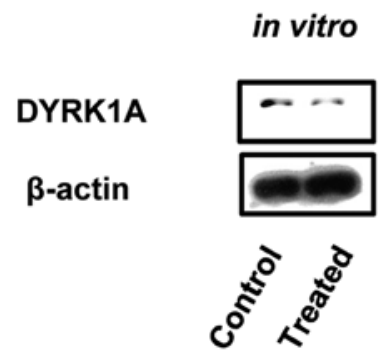

in vivo

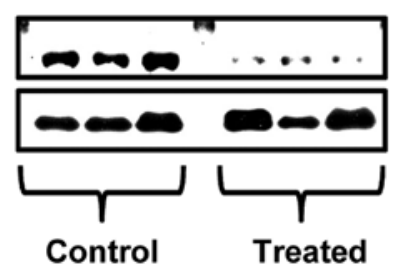

Figure 6. miR-1246 enhances apoptosis in Li-7 cells with downregulation of DTRK1A. (A) WST-8 assay of Li-7 cells after the transfection of miR-1246 mimic with or without $0.1 \mu \mathrm{M}$ galectin-9 for $24 \mathrm{~h}$. miR-1246 was revealed to suppress cell growth only when galectin-9 was administered. (B) WST-8 assay and ELISA of CCK18 performed $48 \mathrm{~h}$ after the transfection of miR-1246 with $0.1 \mu \mathrm{M}$ galectin-9 in Li-7 cells. In the transfection of miR-1246 under galectin-9 in Li-7 cells, CCK18 was significantly upregulated (p<0.0001). (C) WST-8 assay of Li-7 cells after the transfection of miR-6131 mimic with $0.1 \mu$ M galectin-9 for $24 \mathrm{~h}$. miR-6131 did not strengthen the inhibitory effect of galectin-9. (D) Western blot analysis of DYRK1A. The in vitro analysis was done with Li-7 cells incubated with $0.3 \mu \mathrm{M}$ of galectin- 9 for $24 \mathrm{~h}$. The in vivo assay was conducted by three control and three treated xenografts.

fection of miR-1246 in Li-7 cells without galectin-9 treatment. miR-1246 also induced apoptosis with galectin-9 treatment in Li-7 cells (Fig. 6B). These data suggest that miR-1246 acted as the inhibitor molecule of the cell proliferation through apoptosis in Li-7 cells treated with galectin-9. The miR-6131, showed no additional inhibitory effect on the cell growth of Li-7 (Fig. 6C).
Galectin-9 downregulates the expression of DYRK1A, resulting in sensitized caspase-9 activation. We speculated that galectin-9 suppresses the expression level of oncogene DYRK1A through the upregulation of miR-1246 in Li-7 cells and tissues (29). We used cells treated with galectin-9 for $24 \mathrm{~h}$ for in vitro samples. The western blot analysis showed that DYRK1A was downregulated by galectin-9 both in vitro and 
A

\begin{tabular}{|c|c|c|}
\hline & & Seed \\
\hline mIR-1246 & 3' & gguuuuuagguaa \\
\hline Human & 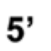 & \\
\hline Chimpanzee & & ACUGUUGUU - GAAUCCAUA \\
\hline Gorilla & & ACUGUUGUU - GAAUCCAUA \\
\hline Orangutan & & NNNNNNNNNN NNNNNNNNN \\
\hline Macaque & & ACUGUUGUU - GAAUCCAUA \\
\hline Olive baboon & & ACUGUUGUU - GAAUCCAUA \\
\hline Marmoset & & ACUGUUGUU - GAAUCCAUA \\
\hline Mouse & & ACUGUUGUU - GAAUCCAUA \\
\hline Rat & & ACUGUUGUU - GACUCCAUA \\
\hline Rabbit & & ACUGUUGUC - GAAUCCAUA \\
\hline Cow & & ACUGUUGUU - GAAUCCAUA \\
\hline Sheep & & ACUGUUGUU - GAAUCCAUA \\
\hline Pig & & ACUGUUGUU - GAAUCCAUA \\
\hline Dog & & AUCCAUA \\
\hline Cat & & ACUGUUGUU - GAAUCCAUA \\
\hline Horse & & ACUGUUGUC - GAAUCCAUA \\
\hline
\end{tabular}

B

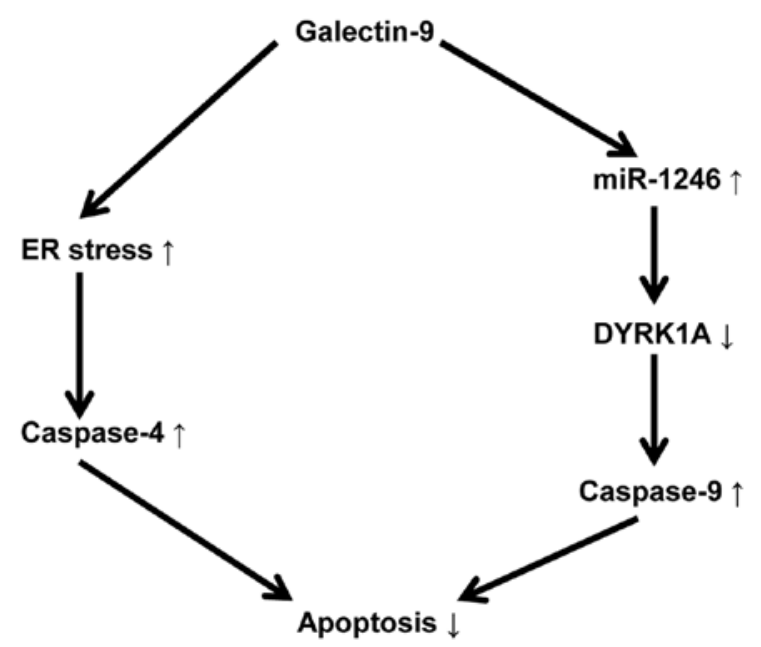

Figure 7. (A) Target sites conserved among 16 mammals. Target sites for miR-1246 found in DYRK1A 3'UTR are aligned among human, mouse and rat. For rat, 6 bases of the seed, the neighboring 3 matches and 3 wobble base pairs are shown to be conserved except for one site of the 7 th base of miR-1246. Vertical bars stand for matched bases (red letters in the seed) and colons for the GU-wobble base pairs (pale red for the contiguous site to the seed). (B) Hypothesis regarding the intracellular mechanism of apoptosis induced by galectin-9. Galectin-9 triggers ER stress and the miR-1246-DYRK1A-caspase-9 axis.

in vivo (Fig. 6D), suggesting that the miR-1246-DYRK1Acaspase-9 axis was involved in the galectin-9-evoked apoptosis. Target sites for miR-1246 found in DYRK1A 3'UTR are conserved among 16 mammals (Fig. 7A).

\section{Discussion}

$\mathrm{HCC}$ is the sixth most frequent malignancy and the third most common cause of cancer-related death worldwide $(1,30)$. Conventional chemotherapy does not always provide significant clinical benefits or prolonged survival for patients with advanced HCC $(30,31)$. It is thus necessary to develop new drugs for the treatment of HCC.

It is evident from several reports that galectin-9, one of the soluble $\beta$-galactoside-binding animal lectins, has a role as an anticancer agent. Accumulated data suggest that recombinant protease-resistant galectin-9 has an antiproliferative effect on cancers such as myeloma (13), melanoma (14), chronic myeloid leukemia (12), B-cell lymphoma (19) and colon cancer (32). However, the antitumor effect of recombinant galectin-9 for HCC remains unknown, and the antitumor mechanisms of galectin-9 in various cancers including $\mathrm{HCC}$ have not been fully clarified. Here we found that recombinant galectin-9 inhibited the growth of HCC cells and tumorigenesis both in vitro and in vivo. We also identified miRNAs that lead to apoptosis associated with the antitumor effect of galectin- 9 in HCC.

In the present study, galectin-9 suppressed the cell proliferation in two HCC cell lines (Li-7 and HLE) in vitro and in vivo by inducing cell apoptosis. In both the in vitro and in vivo experiments, miR-1246 was upregulated in cells and tissues of Li-7 treated with galectin-9, and the transfection of miR-1246 increased the apoptosis under the administration of galectin-9.

The recombinant galectin-9 led to a strong, dose-dependent inhibition of cell proliferation in the HCC cell lines HLE and Li-7, but not in the HCC cell line Huh-7. Although these data suggest that galectin-9 would be a very effective treatment for some HCCs, a question remains as to why was there a difference in the inhibition of cell growth among HCC cell lines. The HLF and Li-7 cells showed the induction of caspase-4 and -9-dependent apoptosis, but it was not independent of Tim-3, a specific ligand of galectin-9. The induction of apoptosis by galectin- 9 did not occur in the Huh-7 cells. These data suggest that the main thrust of the antitumor effect of galectin-9 is to bring about apoptosis.

Our in vivo experiment using subcutaneous HCC-bearing athymic nude mice also demonstrated that galectin-9 suppressed the growth of Li-7 cells, as demonstrated in the in vitro study. The data obtained from the TUNEL staining also indicated that the antitumor effect of galectin-9 was due to apoptosis. These findings suggest that the antitumor effect of galectin-9 may be related to the induction of apoptosis in HCC cells.

MicroRNAs are evolutionarily endogenous noncoding RNAs that have been identified as post-transcriptional regulators of gene expression. The miRNAs bind mainly the 3' untranslated regions (UTRs) of target mRNAs, resulting in mRNA degradation or the blockade of mRNA translation $(31,33)$. miRNAs thus play crucial roles in the cell cycle, differentiation, maturation, functioning and apoptosis of cells. In addition, it has become clear that aberrant miRNA expression is a common feature of various human malignancies (34). In terms of the relationship between miRNAs and HCC, several studies have shown that specific miRNAs are expressed aberrantly in malignant HCC cells or tissues compared to nonmalignant hepatocytes and tissues (31).

However, although miRNAs are becoming increasingly recognized as regulatory molecules in $\mathrm{HCC}$, their involvement in the responses to environmental changes (such as exposure to drugs) remains largely unknown. In the present study, 
using miRNA expression arrays, we determined the variations in miRNA profiles in HCC cell lines both in culture and in xenograft tumor tissues treated with galectin- 9 compared to those not treated with galectin-9. The cluster analyses that we conducted clearly showed that galectin- 9 treatment affected the expression of numerous miRNAs in cultured cells and in tumor tissues. In the analysis, we selected sets of miRNAs that altered their expression levels significantly before and after galectin-9 treatment. We identified 14 miRNAs that were differentially expressed (12 upregulated and two downregulated) in culture and 30 miRNAs that were differentially expressed (14 downregulated and 16 upregulated) in xenograft tumor tissues. These miRNA are candidates for investigations of the effectiveness of galectin-9 treatment and for the search for clues regarding the molecular basis of the anticancer effects of galectin- 9 .

We found that miR-1246 and miR-6131 are upregulated in both cultured cells and tumor tissues treated with galectin- 9 . Zhang et al (29) demonstrated that miR-1246 is associated with apoptosis, targeting and degrading mRNA of oncogene DYRK1A, and making cells more fragile to apoptosis. DYRK1A is a member of the family of therine-threonine kinases, which phosphorylate caspase- 9 and inactivate it, preventing cells from undergoing apoptosis. Our present findings indicate that the upregulation of miR-1246 was accompanied by a downregulation of DYRK1A and upregulation of caspase-9. We thus speculate that the anticancer effect of galectin-9 is due not only to ER stress, but also apoptosis via a mitochondrial pathway through the miR-1246DYRK1A-caspase-9 axis (Fig. 7B). In previous studies, and in our present study, miR-1246 was upregulated in cancer cells after treatment with an anticancer agent $(21,22,35,36)$. Cancers originated from various organs might owe their proliferation to regulating miR-1246-DYRK1A-caspase-9 axis because this pathway is highly conserved among species (Fig. 7A). The mechanism of cooperation between miR-1246 and DYRK1A remains to be further investigated. The role of miR-6131 remains unknown, and it is possible that miR-6131 has no role in the suppression of cancer progression.

Our data suggest that the mechanism of the anticancer molecule galectin-9 is unique. The main role of antitumor effects of galcetin-9 appears to depend on the induction of the apoptosis of cancer cells, not the arrest of the cell cycle. To date, several anticancer drugs used for HCC, i.e., sorafenib, cisplatin and fluorouracil (5-FU) were shown to induce the arrest of the cell cycle (37). We thus propose the possibility of using galectin-9 to treat HCC patients in combination with other anticancer drugs that induce cell cycle arrest. In addition, because galectin- 9 is stabilized against protease in sera, intravenous galectin- 9 treatment is expected to have antitumor effects for patients with HCC (17).

In conclusion, our main findings are that galectin-9 inhibited the growth of two HCC cell lines and primary human HCCs both in vitro and in vivo through apoptosis, and that miR-1246 mediated the signals of galectin-9, possibly through the downregulation of DYRK1A and upregulation of caspase-9. Recombinant galctin-9 is a new potential therapeutic target for HCC that may overcome resistance to conventional chemotherapy as an adjunct to conventional chemotherapy. Clinical studies of galcetin- 9 as a new anticancer agent thus seem appropriate.

\section{Acknowledgements}

Toshiro Niki and Mitsuomi Hirashima are board members of GalPharma Co., Ltd. The two authors have the following patents related to material pertinent to this article: 'Novel modified galectin 9 proteins and use thereof' which is applied by GalPharma and issued in Japan (4792390), the USA $(8,268,324)$, EPC (1736541), Canada (2,561,696), India (239130), and Korea [(10-1222281) as of 2013.12.2]. The two authors have the following products related to material pertinent to this article: stable-form Gal-9.

\section{References}

1. Forner A, Llovet JM and Bruix J: Hepatocellular carcinoma. Lancet 379: 1245-1255, 2012.

2. Meza-Junco J, Montano-Loza AJ, Liu DM, Sawyer MB, Bain VG, $\mathrm{Ma} \mathrm{M}$ and Owen R: Locoregional radiological treatment for hepatocellular carcinoma; Which, when and how? Cancer Treat Rev 38: 54-62, 2012.

3. Llovet JM, Ricci S, Mazzaferro V, Hilgard P, Gane E, Blanc JF, de Oliveira AC, Santoro A, Raoul JL, Forner A, et al: SHARP Investigators Study Group: Sorafenib in advanced hepatocellular carcinoma. N Engl J Med 359: 378-390, 2008.

4. Bruix J, Raoul JL, Sherman M, Mazzaferro V, Bolondi L, Craxi A, Galle PR, Santoro A, Beaugrand M, Sangiovanni A, et al: Efficacy and safety of sorafenib in patients with advanced hepatocellular carcinoma: Subanalyses of a phase III trial. J Hepatol 57: 821-829, 2012.

5. Wada J, Ota K, Kumar A, Wallner EI and Kanwar YS: Developmental regulation, expression, and apoptotic potential of galectin-9, a beta-galactoside binding lectin. J Clin Invest 99: 2452-2461, 1997.

6. Matsumoto R, Matsumoto H, Seki M, Hata M, Asano Y, Kanegasaki S, Stevens RL and Hirashima M: Human ecalectin, a variant of human galectin-9, is a novel eosinophil chemoattractant produced by T lymphocytes. J Biol Chem 273: 16976-16984, 1998.

7. Zhu C, Anderson AC, Schubart A, Xiong H, Imitola J, Khoury SJ, Zheng XX, Strom TB and Kuchroo VK: The Tim-3 ligand galectin-9 negatively regulates $\mathrm{T}$ helper type 1 immunity. Nat Immunol 6: 1245-1252, 2005.

8. Rabinovich GA, Liu FT, Hirashima M and Anderson A: An emerging role for galectins in tuning the immune response: Lessons from experimental models of inflammatory disease, autoimmunity and cancer. Scand J Immunol 66: 143-158, 2007.

9. Nagahara K, Arikawa T, Oomizu S, Kontani K, Nobumoto A, Tateno $\mathrm{H}$, Watanabe $\mathrm{K}$, Niki T, Katoh S, Miyake M, et al: Galectin-9 increases Tim- $3^{+}$dendritic cells and CD8 ${ }^{+} \mathrm{T}$ cells and enhances antitumor immunity via galectin-9-Tim-3 interactions. J Immunol 181: 7660-7669, 2008.

10. Fujihara S, Mori H, Kobara H, Rafiq K, Niki T, Hirashima M and Masaki T: Galectin-9 in cancer therapy. Recent Pat Endocr Metab Immune Drug Discov 7: 130-137, 2013.

11. Wiersma VR, de Bruyn M, Helfrich W and Bremer E: Therapeutic potential of Galectin-9 in human disease. Med Res Rev 33 (Suppl 1): E102-E126, 2013.

12. Kuroda J, Yamamoto M, Nagoshi H, Kobayashi T, Sasaki N, Shimura Y, Horiike S, Kimura S, Yamauchi A, Hirashima M, et al: Targeting activating transcription factor 3 by Galectin- 9 induces apoptosis and overcomes various types of treatment resistance in chronic myelogenous leukemia. Mol Cancer Res 8: 994-1001, 2010.

13. Kobayashi T, Kuroda J, Ashihara E, Oomizu S, Terui Y, Taniyama A, Adachi S, Takagi T, Yamamoto M, Sasaki N, et al: Galectin-9 exhibits anti-myeloma activity through JNK and p38 MAP kinase pathways. Leukemia 24: 843-850, 2010.

14. Kageshita T, Kashio Y, Yamauchi A, Seki M, Abedin MJ, Nishi N, Shoji H, Nakamura T, Ono T and Hirashima M: Possible role of galectin-9 in cell aggregation and apoptosis of human melanoma cell lines and its clinical significance. Int J Cancer 99: 809-816, 2002.

15. Zhang ZY, Dong JH, Chen YW, Wang XQ, Li CH, Wang J, Wang GQ, Li HL and Wang XD: Galectin-9 acts as a prognostic factor with antimetastatic potential in hepatocellular carcinoma. Asian Pac J Cancer Prev 13: 2503-2509, 2012. 
16. Li H, Wu K, Tao K, Chen L, Zheng Q, Lu X, Liu J, Shi L, Liu C, Wang $\mathrm{G}$, et al: Tim-3/galectin-9 signaling pathway mediates T-cell dysfunction and predicts poor prognosis in patients with hepatitis B virus-associated hepatocellular carcinoma. Hepatology 56: 1342-1351, 2012.

17. Nishi N, Itoh A, Fujiyama A, Yoshida N, Araya S, Hirashima M, Shoji H and Nakamura T: Development of highly stable galectins: Truncation of the linker peptide confers protease-resistance on tandem-repeat type galectins. FEBS Lett 579: 2058-2064, 2005.

18. Nishikawa T, Nakajima T, Moriguchi M, Jo M, Sekoguchi S, Ishii M, Takashima H, Katagishi T, Kimura H, Minami M, et al: A green tea polyphenol, epigalocatechin-3-gallate, induces apoptosis of human hepatocellular carcinoma, possibly through inhibition of Bcl-2 family proteins. J Hepatol 44: 1074-1082, 2006.

19. Kashio Y, Nakamura K, Abedin MJ, Seki M, Nishi N, Yoshida N, Nakamura T and Hirashima M: Galectin-9 induces apoptosis through the calcium-calpain-caspase-1 pathway. J Immunol 170: 3631-3636, 2003

20. Martin SJ, Reutelingsperger CP, McGahon AJ, Rader JA, van Schie RC, LaFace DM and Green DR: Early redistribution of plasma membrane phosphatidylserine is a general feature of apoptosis regardless of the initiating stimulus: Inhibition by overexpression of Bcl-2 and Abl. J Exp Med 182: 1545-1556, 1995.

21. Kato K, Gong J, Iwama H, Kitanaka A, Tani J, Miyoshi H, Nomura K, Mimura S, Kobayashi M, Aritomo Y, et al: The antidiabetic drug metformin inhibits gastric cancer cell proliferation in vitro and in vivo. Mol Cancer Ther 11: 549-560, 2012.

22. Kobayashi M, Kato K, Iwama H, Fujihara S, Nishiyama N, Mimura S, Toyota Y, Nomura T, Nomura K, Tani J, et al: Antitumor effect of metformin in esophageal cancer: In vitro study. Int J Oncol 42: 517-524, 2013

23. Schutte B, Henfling M, Kölgen W, Bouman M, Meex S, Leers MP, Nap M, Björklund V, Björklund P, Björklund B, et al: Keratin 8/18 breakdown and reorganization during apoptosis Exp Cell Res 297: 11-26, 2004.

24. Workman P, Aboagye EO, Balkwill F, Balmain A, Bruder G, Chaplin DJ, Double JA, Everitt J, Farningham DA, Glennie MJ, et al: Committee of the National Cancer Research Institute: Guidelines for the welfare and use of animals in cancer research. Br J Cancer 102: 1555-1577, 2010.

25. Tamura T, Fujita F, Tanimoto M, Koike M, Suzuki A, Fujita M, Horikiri Y, Sakamoto Y, Suzuki T and Yoshino H: Anti-tumor effect of intraperitoneal administration of cisplatin-loaded microspheres to human tumor xenografted nude mice. J Control Release 80: 295-307, 2002
26. Miyoshi H, Kato K, Iwama H, Maeda E, Sakamoto T, Fujita K, Toyota Y, Tani J, Nomura T, Mimura S, et al: Effect of the antidiabetic drug metformin in hepatocellular carcinoma in vitro and in vivo. Int J Oncol 45: 322-332, 2014.

27. Bolstad BM, Irizarry RA, Astrand M and Speed TP: A comparison of normalization methods for high density oligonucleotide array data based on variance and bias. Bioinformatics 19: 185-193, 2003.

28. Rao RV, Ellerby HM and Bredesen DE: Coupling endoplasmic reticulum stress to the cell death program. Cell Death Differ 11: 372-380, 2004.

29. Zhang Y, Liao JM, Zeng SX and Lu H: p53 downregulates Down syndrome-associated DYRK1A through miR-1246. EMBO Rep 12: 811-817, 2011.

30. Asghar U and Meyer T: Are there opportunities for chemotherapy in the treatment of hepatocellular cancer? J Hepatol 56: 686-695, 2012.

31. Callegari E, Elamin BK, Sabbioni S, Gramantieri L and Negrini M: Role of microRNAs in hepatocellular carcinoma: A clinical perspective. Onco Targets Ther 6: 1167-1178, 2013.

32. Nobumoto A, Nagahara K, Oomizu S, Katoh S, Nishi N, Takeshita K, Niki T, Tominaga A, Yamauchi A and Hirashima M: Galectin-9 suppresses tumor metastasis by blocking adhesion to endothelium and extracellular matrices. Glycobiology 18: 735-744, 2008.

33. Kerr TA, Korenblat KM and Davidson NO: MicroRNAs and liver disease. Transl Res 157: 241-252, 2011.

34. Calin GA and Croce CM: MicroRNA signatures in human cancers. Nat Rev Cancer 6: 857-866, 2006.

35. Kushibiki T, Hirasawa T, Okawa S and Ishihara M: Regulation of miRNA expression by low-level laser therapy (LLLT) and photodynamic therapy (PDT). Int J Mol Sci 14: 13542-13558, 2013.

36. Bach D, Fuereder J, Karbiener M, Scheideler M, Ress AL, Neureiter D, Kemmerling R, Dietze O, Wiederstein M, Berr F, et al: Comprehensive analysis of alterations in the miRNome in response to photodynamic treatment. J Photochem Photobiol B 120: 74-81, 2013.

37. Deng L, Ren Z, Jia Q, Wu W, Shen H and Wang Y: Scheduledependent antitumor effects of 5-fluorouracil combined with sorafenib in hepatocellular carcinoma. BMC Cancer 13: 363, 2013. 